\title{
The Concept of Slack and the Comprehensive Opportunity and Lost Opportunity Control Model
}

\author{
Akira Nishimura ${ }^{1}$ \\ ${ }^{1}$ Emeritus Professor of Kyushu University, Visiting Professor of Beppu University, Japan \\ Correspondence: Akira Nishimura, Emeritus Professor of Kyushu University, Visiting Professor of Beppu \\ University, Japan. E-mail: ztd03361@nifty.com
}

Received: April 12, 2019

doi:10.5539/ijbm.v14n8p95

\begin{abstract}
Enterprise slack, defined as undistributed profit and earned surplus, is a key factor to consider when developing enterprise strategy based on opportunity and risk management. Slack also provides an unrestricted, but indispensable, financial resource for firms to carry out improvement and innovation, exploitation and exploration, and financial activities according to their strategy. In the comprehensive opportunity and lost opportunity control model previously developed by the author (Nishimura, 2015; 2016), slack fulfills its function effectively. Therefore, to make the model more practicable and functional, this paper will examine the substance and functions of slack more definitely by analyzing financial slack and its relationship with business strategy in five innovative manufacturing companies in Japan.
\end{abstract}

Keywords: enterprise slack, quality of earnings, feed forward accounting control, investment and financial strategy, opportunity and risk management

\section{Introduction}

In Management, Uncertainty, and Accounting: Case Studies, Theoretical Models, and Useful Strategies, published in 2019 by Palgrave Macmillan, (Note 1) I characterize contemporary management accounting using the comprehensive opportunity and lost opportunity control (COLC) model and examine how enterprises must recognize and control business activities in an uncertain environment by using integrated management with feed forward accounting control and profit opportunity/risk management. In particular, the model addresses how enterprises can cope with foreign exchange risk and the failure of derivative transactions through management accounting. The COLC model leads to a target profit for strategic profit management by forecasting profit opportunity/risk from the two strategic viewpoints of long-term sustainable growth and current market competition and carrying out proactive improvement and innovation for the reduction of forecast variance between these long-term and current profit opportunities/risks. Then, it helps identify the strengths of efficient and effective activities in the whole organization to actualize the target profit. As a result of variance analysis between the target profit and actual profit, this model can provide managers with useful variance information for planning optimal profit in the next accounting period. After all, this model presents a synthesized accounting control system from target profit planning through proactive variance analysis of profit opportunity/risk and preventive improvement and innovation to target profit management in connection with reactive revenue and cost management, in which cost design (target costing) is also included. This process results in the strengthening of current market competitive power based on a sustainable growth strategy.

In the abovementioned book, I describe the COLC model on the premise that enterprises possess financial slack, which is undoubtedly needed for improvement and innovation. However, slack should be more clearly incorporated into the model in order to capture this process in a more concrete manner. Unfortunately, this aspect of the model was not examined in the book. Therefore, we must examine what slack is, what relation it has to enterprise business strategy, and how it is recognized in accounting, and then to connect slack with improvement and innovation or effective and efficient management. Because the author proposes to disclose management reports on the enterprise risk situation and countermeasures against it to stakeholders in order to fulfill the enterprise's social responsibility, the publication of risk-counterplot and financial slack, which will be studied in this paper, may enrich the soundness of business practices and the trustworthiness of the report. To analyze the practical situation of financial slack and its impact on cash flow in light of these issues, this paper uses data 
related to financial slack from five of Japan's most innovative companies in the manufacturing industry (Note 2) to develop a more practical and effective COLC model in which slack is accounted for as a central feature.

\section{Literature Review: Roles and Functions of Slack}

\subsection{Concept of Slack in Imai's Theory}

The idea of slack as a financial buffer in enterprises is often associated with the situation where the chief manager in a section gains extra flexibility by underestimating the section's planned value or overestimating its performance beforehand in order to secure its independence and flexibility in the context of the enterprise's whole budget and the associated restrictions, or to obtain an advantageous evaluation of its performance, when this additional buffer materializes. Therefore, this has been considered the "dysfunction" of slack since it produces inconsistency between the optimum usage of overall funds and sectional flexible usage, which results in a negative expected effect for the overall enterprise financial situation. In contrast, Imai (2014) emphasizes the "eufunction" (positive function) of slack and describes it as follows: "In Toyota performance management accounting slack fulfills its function as a factor of function in enterprises management where enhanced measures for cost-competitive power (cost-reduction measures) are additionally created and profit planning and control is refined to cope adequately with the external business environment" (Imai, 2016).

According to Imai's idea of "eufunction," slack signifies financial leeway that a firm can use to cope with external environmental changes since it is secured through strengthening cost-competitiveness by means of cost reduction and cost improvement in the whole organization, including each sector, rather than for securing sectional independence and flexibility from the whole business budget of an organization. Imai, focusing on cost improvement as the factor that creates slack for the whole business of a firm, including each sector, refers to its meanings as follows: "It contributes to raising business quality as an organizational business system in an enterprise through promoting improvement activity by total employee-participation in every workplace of the company" (p. 45). Imai poses an important question for business management in the present uncertain business environment after examining the slack of the whole organization and activities for its formation in the context of Toyota's performance management accounting practices.

In this case, how can an accounting system recognize and control the slack created by cost improvement activity? Although, as Imai described definitely, for slack we recognize profit and earned reserve as the accumulation of slack in terms of accounting because cost improvement and cost reduction brings forth revenues and profit, and make new investment possible, this paper aims to more concretely examine the accounting function and meanings of slack from a strategic planning perspective and to clarify its relationship with the COLC model.

\subsection{Financial Slack and Undistributed Profit (Internal Reserve)}

In today's strongly uncertain business environment, enterprises should consider the opportunities and risks connected to uncertainty above all else in business management and always examine financial slack in relation to them. Concerning the relationship between slack and investment strategy, Chung and Wright (1998) summarize as the conclusion of their research as follows: "For firms with growth opportunities, however, too much debt is unfavorably viewed by the market. In addition, financial slack and R\&D expenditures are favorably received by the market for growth firms but not for over-investing firms" (p. 302). Myers and Majluf (1984) clearly consider financial slack as "cash or marketable securities or [the] ability to issue default-risk-free debt" that allows a firm to "avoid external financing and to disentangle investment decision from conflicts of interest between old stockholders and new investors," which then allows firms to seize valuable investment opportunities (Chung \& Wright).

As stated above, enterprise managers would give internal reserve funds or financial slack preference in order to actualize investment opportunities without the restrictions of financing cost and asymmetric information between management and stockholders, and internal stockholders and potential investors. Financial slack is funding to actualize investment opportunities, rather than rely on bank borrowing or the issuance of stock. It has been shown that small-sized high-tech enterprises, as well as large enterprises, have depended on internal cash flow, not external funds, for R\&D investment (Carpenter and Petersen, 2002; Hall, 1992; Sasaki, 2007a, 2007b, 2008) (Note 3).

Because the COLC model seeks sustainable growth for enterprises in an uncertain business environment, it also needs to pay attention to slack in relation to investment opportunities and external financing. Furthermore, the model must address the formation of slack through cost improvement and cost design, which are also regulated by business strategies such as merger and acquisition, the transfer of manufacturing operations overseas under today's rapidly progressing technical innovation and information revolution, and the expansion of global market 
competition. Financial slack should be synthetically examined from both the viewpoints of business growth strategy and opportunity and risk management.

\subsection{Slack and Business Growth}

Although the author has examined sustainable enterprise growth from the perspectives of improvement and innovation such as cost reduction and cost improvement, the reform of production structures, and the creation of new business value, recent research has more definitely characterized business improvement and innovation as ambidexterity and the balance of exploitation and exploration. In this case, exploitation encompasses business activities or investments that have the special characteristics of being certain, providing short-term benefit, or being a formality, routine, and standardized; on the other hand, the activities of exploration are uncertain, may provide long-term benefit, and can be viewed as unique, non-routine, and outside the scope of business as usual (Gschwanntner \& Hiebl, 2016; Ylinen \& Gulkvist, 2014). In reference to marketing, Josephson, Johnson \& Mariadoss (2016) also explain exploitation as extracting value from existing offerings and solutions (existing market opportunities) and exploration as the search for and development of new value opportunities (p. 539). Therefore, from the viewpoint of sustainable business growth, we should discuss how a firm uses the two different investment activities (exploitation and exploration) equally well and holds their balance. Gschwantner and Hiebl (2016), referring to other researchers' studies, point out the necessity of managing exploitation and exploration successfully by using "a wide range of management control systems" (p. 401). According to Ylinen and Gullkvist (2014), the results of their study "suggest that the interaction effect of organic control and mechanistic control enhances performance in both exploratory and exploitative innovation projects, and [they] support a complementary effect" (p. 107). Gurd and Helliar (2017), taking notice of the importance of institutional leaders in balancing innovation and risk management, state the following: "Overall, innovation and risk management may be balanced when institutional leaders support innovation as a value yet create and maintain important mundane administrative arrangements. The problem of balance for leaders may be creating and maintaining innovation in the exploitation stage and risk management in the exploration stage" (pp. 100-101). They then summarize, on the basis of case studies of two companies, that given the prevailing engineering logic of both companies, it was not surprising that accounting and accountants were marginalized ( $\mathrm{p}$. 99), going on to stress the importance of accountants in providing leadership in balancing innovation and risk management controls. After all, ambidexterity and the balance of exploitation and exploration allows enterprises to maintain and make the most of existing value and create new future value.

As shown above, ambidexterity and the balance of exploitation and exploration not only are related to organization and management control (O'Reilly \& Tushman, 2013), but are also a main issue in terms of business strategic planning for opportunity/risk management. At the same time, every enterprise should first consider financial slack when structuring its organization and management systems for executing strategic investment plans from the viewpoint of sustainable growth and competitiveness. Under an uncertain business environment, financial slack is a key factor for enterprises when balancing exploitative investment with explorative investment and sustaining business growth; it allows enterprise managers to make good use of slack based on accounting control and management systems and to create profit opportunities together with the reduction of risks or the transformation of risks into profit opportunities.

Slack does not represent the degree of sectional autonomy from or flexibility within the whole organization's budget, but rather the financial slack to execute the general strategies of the enterprise to pursue growth based on opportunities/risks and global competitiveness. Although the COLC model is premised with financial slack as an indispensable factor to cope with daily or extraordinary opportunities/risks, internal reserve (undistributed profit) and its accumulated amounts (earned surplus) must be more definitely specified as financial slack in the model, as they are backed by cash flow to support exploitative and explorative investments. Internal reserve can be seen as the flow of slack and earned reserve as the stock. Thus, together they form the whole slack in an enterprise, so it is reasonable to name them "enterprise slack" (Note 4).

The importance of enterprise slack is more firmly decided by whether an enterprise has sufficient enterprise slack to maintain sustainable business growth and to secure market competitive power, rather than whether internal funds and external funding are more favorable to effective investment. Therefore, for strategic mobility, enterprise slack must be evaluated from the angle not only of the flow of undistributed profit in a given period and not the profit itself, but also the earned surplus as stock, and their relation to cash flow.

\subsection{Slack and Risk Management}

Foreign exchange risk influences slack in terms of both flow and stock. First, this section will examine the effect of foreign exchange gain/loss on slack in flow and stock in five Japanese manufacturing companies. Table 1 
shows that earned surpluses in these companies were heavily hurt by the economic downturn precipitated by the Lehman Brothers bankruptcy in 2008 and, in particular, this shock was greater to companies with low accumulated earned surplus. Even though its negative influence may be offset through exchange gains in the process of business recovery, companies with weak financial slack as flow and stock would take a longer time and pay more to recover since their business fundamentals were heavily injured by the sudden exchange loss.

Uncertainty is surely a regular occurrence in the enterprise business environment. Although foreign currency translation loss is unrealized and treated as all-inclusive income under accounting rules, this loss passively injures slack as stock (earned surplus) and influences the future direction of business. It must not be overlooked that global fluctuation in foreign exchange during times such as the Lehman Brothers bankruptcy exerted serious influences on the businesses' foundation and was cause for concern. Even if foreign currency translation losses have some possibility of being offset through foreign currency translation gains over a longer period of time, these losses reduce slack as stock and weaken the business foundation, which can then exert such a serious effect on business that companies cannot recover from this impact through gains, even over the long term.

Table 1. Foreign currency translation adjustment and its effects on earned surplus in five Japanese manufacturing companies, 2007-2009 (FCT in millions of yen)

\begin{tabular}{lllllllllll}
\hline & \multicolumn{2}{l}{ Company A } & \multicolumn{2}{l}{ Company B } & \multicolumn{2}{l}{ Company C } & \multicolumn{2}{c}{ Company D } & \multicolumn{2}{c}{ Company E } \\
Year & FCT & Effect & FCT & Effect & FCT & Effect & FCT & Effect & FCT & Effect \\
\hline $\mathbf{2 0 0 7}$ & 0 & $0.0 \%$ & $-4,612$ & $-3.72 \%$ & $-3,123$ & $-6.07 \%$ & -486 & $-2.99 \%$ & -462 & $-5.66 \%$ \\
2008 & $-2,607$ & $-8.96 \%$ & $-4,002$ & $-3.47 \%$ & $-4,972$ & $-9.67 \%$ & 1,446 & $17.63 \%$ & -742 & $-11.16 \%$ \\
2009 & 334 & $1.1 \%$ & 156 & $0.13 \%$ & 968 & $1.81 \%$ & 69 & $0.97 \%$ & -723 & $-11.13 \%$ \\
\hline
\end{tabular}

Note. $\mathrm{FCT}=$ foreign currency translation adjustment.

Table 2 shows the impact that foreign currency translation gains and losses had on free cash flow (i.e., cash flow from operating activities minus cash flow from investment activities) over a fourteen-year period from April 2004 to March 2018 for the five Japanese firms. Companies A, B, and C have foreign currency translation losses, while Companies D and E have gains. The largest loss amount is Company B, followed by Company C, while the gains of both Companies D and $\mathrm{E}$ are comparatively low.

Table 2. Foreign currency translation gains or losses as a percent of free cash flow for five Japanese companies, 2004-2018 (in millions of yen)

\begin{tabular}{llll}
\hline Company & $\begin{array}{l}\text { Free } \\
\text { cash flow } \\
\text { (a) }\end{array}$ & $\begin{array}{l}\text { Foreign currency translation } \\
\text { gains/losses } \\
\text { (b) }\end{array}$ & $\begin{array}{l}\text { Gain/loss as a percent of free } \\
\text { cash flow } \\
\text { (b/a) }\end{array}$ \\
\hline A & $+30,082$ & -734 & $-2.44 \%$ \\
B & $-22,687$ & $-2,479$ & $+10.93 \%$ \\
C & $+2,375$ & -844 & $-35.54 \%$ \\
D & $+17,636$ & +225 & $+1.28 \%$ \\
E & $-6,203$ & +147 & $-2.37 \%$ \\
\hline
\end{tabular}

Regarding the impact of the gain/loss on free cash flow, Company C is the highest, followed by Company B. Both of these firms are in the automobile industry and had expanded their business overseas, which increased their foreign exchange risk. In contrast, the impact of gains and losses for Companies D and E are comparatively are low. It is also clear from the above situation that today risk management becomes important for enterprises to manage ordinary business, especially when expanding overseas.

The effect of foreign currency translation on financial slack became more acute for these companies before and after the Lehman shock in 2008. In the present day, when most firms seek to strengthen overseas investment and organize global supply chains, it is an important, yet commonplace, subject in business management to plan for and control market risks, foreign exchange risks, and derivatives connected with these risks. (Note 5) Enterprises that focus mainly on manufacturing should always develop a business strategy by forecasting profit opportunities and risks. In these cases, they cannot sufficiently account for opportunities and risks without enterprise slack. Sakanaka (2017) aptly says "because enterprises do not always continue to be profitable business, they should 
not forget that the accumulation of undistributed profit has also 'an aspect of preparation for business risks." Moreover, Josephson, Johnson and Mariadoss (2016), referring to other researchers' papers, clearly describe the substance of slack as follows: "Slack provides a useful tool for a firm to respond to market fluctuations in a speedy and effective manner----increasing the range of its strategic options" and then "It [Financial slack] underpins the level of financial flexibility a firm possesses to deal with internal and/or external issues or opportunities that may develop." (p. 542)

Next, to clarify the synthetic meanings of enterprise slack in the COLC model, this paper will analyze the financial data of the aforementioned five manufacturing companies in relation to the roles and functions of slack mentioned above and clarify how enterprise slack is intertwined with sustainable business growth and competitive strategy.

\section{Financial Data Analysis: Enterprise Slack and Business Strategy}

\subsection{Trends of Enterprise Slack in the Five Companies}

We will first consider the practical situation of enterprise slack in the five innovatively representative Japanese companies from the two angles of stock and flow. Figure 1 shows the trend of earned surplus for 14 years from April 2004 to March 2018 in the five companies.

As for the trends for earned surplus (slack as stock), Companies A, B, and C have continued to ascend, with some changes, for 14 fiscal years, with the 2004 fiscal year as the base period of 1 . In Company D, its level in the 2017 fiscal year returns to the same as that in the 2004 fiscal year due to a temporary fall, but its growth rate is weaker than the first three companies. In contrast with the trends in these companies, the situation of Company E has been stagnant since 2012 when the amount of slack fell to its lowest level, and earned surplus has not returned to the level of the 2004 fiscal year. As can be seen in the trends for these five companies over 14 years, even the most innovative companies find it very difficult to insure the favorable growth of slack as stock under today's uncertain business environment.

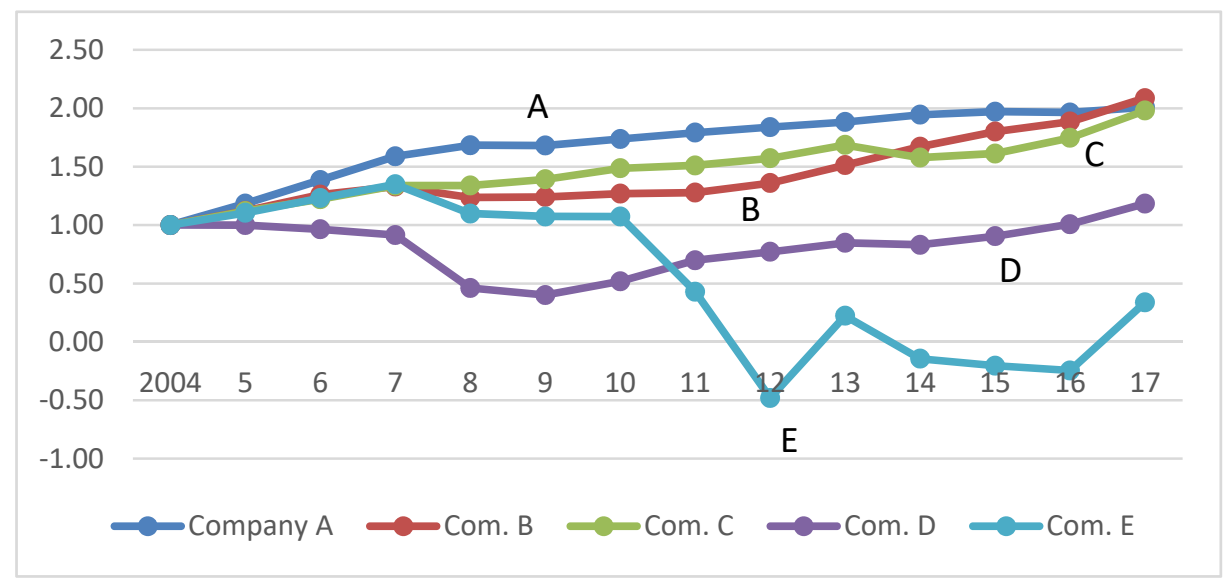

Figure 1. Trends in earned surplus for five Japanese companies, 2004-2017

Note. $\mathrm{y}$-axis=earned surplus values indexed to 2004, with a base value of 1 .

These trends are closely connected with the situation of undistributed profit (slack as flow). Figure 2 indicates the change in slack as flow (undistributed profits) for the 14 fiscal years from 2004 to 2017. The three companies (A, B, and C) with increasing slack as stock continue to maintain similar levels of undistributed profits as in the 2004 fiscal year, with minimal variation year to year. In contrast to this situation, for Company D, the level of undistributed profits in the 2017 fiscal year far exceeds that of 2004, despite a temporary fall around 2008. For Company E, undistributed profits in 2017 are the same as in 2004, but with lower levels in the several of the intervening years. 


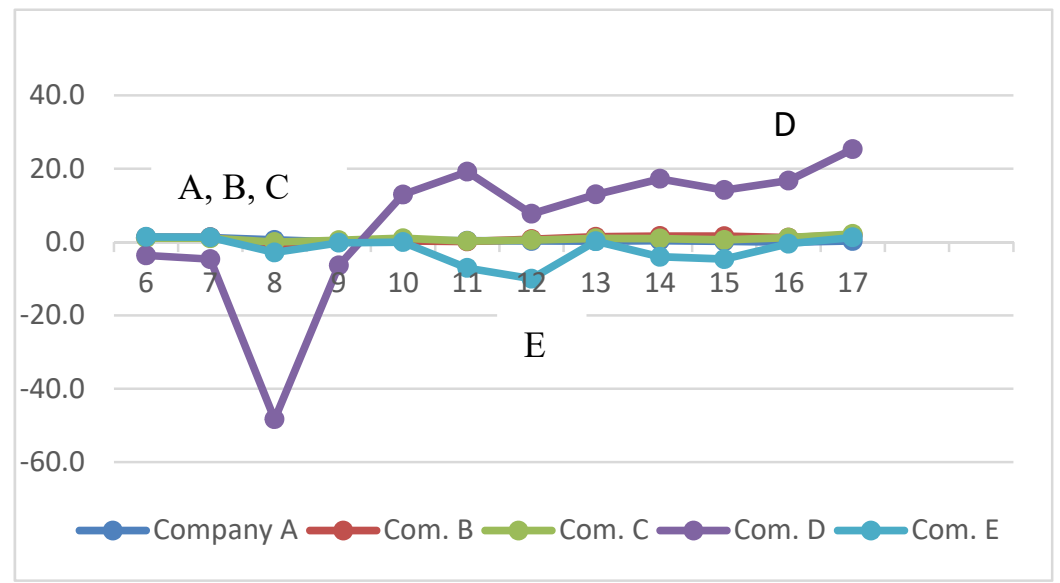

Figure 2. Trends in undistributed profits for five Japanese companies, 2004-2017

Over the whole period, Companies A, B, and C maintained comparatively stable slack as flow and strengthened slack as stock; whereas in Companies D and E, slack as stock was impacted by occasional fluctuations in slack as flow. Specifically, in Company D, slack as stock was greatly affected by strong fluctuation in slack as flow (i.e., the sinking and restoration in undistributed profits), yet still ended up at a higher level than in 2004; in Company E, the decline in undistributed profit resulted in decreased accumulated earned surplus (slack as stock). These situations can be clearly be recognized through the undistributed profit ratio and the ratio of earned surplus to total assets (see Table 3).

Table 3. Average undistributed profit ratio and the ratio of earned surplus to total assets, 2004-2017

\begin{tabular}{llccll}
\hline Company & A & B & C & D & E \\
\hline Undistributed profit ratio & $52.5 \%$ & $71 \%$ & $75.6 \%$ & $68.4 \%$ & $117.4 \%$ \\
Ratio of earned surplus to total assets & $68.6 \%$ & $36.7 \%$ & $40.4 \%$ & $14.1 \%$ & $14.2 \%$ \\
\hline
\end{tabular}

From this, we can see that Companies $\mathrm{B}$ and $\mathrm{C}$ ensured the foundation for slack by maintaining a high undistributed profit ratio, whereas Company A did so through a continually stable undistributed profit ratio. In contrast, Company D weakened its foundation for slack by allowing temporary up and down fluctuations in undistributed profit ratio despite its long-range stability, and Company E not only had low earned surplus, but also, because it had a very high ratio of undistributed profit ratio over $100 \%$, used earned surplus only for dividends rather than for building a proper foundation for slack.

Although we have mainly examined enterprise slack from accounting angle, the next section inquires into enterprise slack in relation to the quality of operating profit, or cash flow, and clarifies its actual condition in connection with investment and finance activities in order to make slack's relationship in the COLC model clearer. Although the quality of operating profit in the five companies seems to be generally sound, as shown in Table 4, these numerical values do not always represent the actual condition of their businesses or the true quality of the profit. To gauge their true meanings, the transition (growth ratio) of these values should be analyzed in terms of operating earnings and cash flows from operating activities.

\subsection{Enterprise Slack and Quality of Operating Earnings}

As Table 4 shows, Companies A, B, C, and D maintained a stable quality of operating earnings over the 14-year period, with Company $\mathrm{E}$ being the lone outlier in this regard. Quality of operating earnings for the first four companies is the highest in Company B and the lowest in Company A. However, for 2017, Company A scored better than Company B in terms of operating earnings. It should be noted that the quality of operating earnings does not immediately reflect the substance of enterprise slack. Table 5 shows the relationship between operating earnings and cash flow from operating activities in four fiscal years (2008, 2012, 2016, and 2017), with the 2004 fiscal year used as the baseline equal to one. The results in this table are discussed further below. 
Table 4. Quality of operating earnings for five Japanese companies, 2004-2017

\begin{tabular}{llllll}
\hline Company & $\mathrm{A}$ & $\mathrm{B}$ & $\mathrm{C}$ & $\mathrm{D}$ & $\mathrm{E}$ \\
\hline $\begin{array}{l}\text { Quality of operating earnings } \\
\text { (14-year average) }\end{array}$ & 1.36 & 1.83 & 1.52 & 1.55 & 2.91 \\
$\begin{array}{l}\text { Quality of operating earnings } \\
\text { (2017 fiscal year) }\end{array}$ & 1.78 & 1.75 & 1.18 & 1.02 & 1.17 \\
$\begin{array}{l}\text { Ratio of depreciation expenses to operating } \\
\text { profit }\end{array}$ & 0.734 & 0.579 & 0.802 & 0.944 & $\mathbf{4 . 0 6 7}$ \\
$\begin{array}{l}\text { Ratio of depreciation expenses to cash flow } \\
\text { from operating activities }\end{array}$ & 0.539 & 0.317 & 0.528 & 0.610 & $\mathbf{1 . 4 0 0}$ \\
\hline
\end{tabular}

Note. Quality of operating earnings is the ratio of operating earnings to cash flow from operating activities.

First, it is certain that the Leman Brothers' bankruptcy caused a serious blow to the businesses of all five companies before and after 2008. Three companies (A, B, and C) that possessed plenty of slack backed by cash or assets were able to cope with such risk and recover their businesses to 2004 levels following the Lehman shock. However, Companies D and E were not able to reach their original sound condition. It is certain from these observations that enterprise slack is closely connected with the ability to cope with risks or is deeply related to planning for and controlling opportunities and risks that decide the direction of investment and financial activities. For this issue, we examine the quality of operation profit in the five companies more concretely.

Table 5. Quality of operating earnings and cash flow from operating activities for five Japanese companies in selected years, 2004-2017

\begin{tabular}{llllll}
\hline Fiscal year & 2004 & 2008 & 2012 & 2016 & 2017 \\
\hline Company A & & & & & \\
Operating earnings & 1.0 & $\mathbf{0 . 9 1 2}$ & $\mathbf{0 . 5 9 6}$ & 0.421 & 0.610 \\
Cash flow from operating activities & 1.0 & 1.098 & $\mathbf{0 . 6 8 4}$ & 0.891 & 1.052 \\
Quality of operating earnings & 1.0 & 1.204 & 1.148 & 2.117 & 1.725 \\
Depreciation expenses & 1.0 & 1.358 & 1.077 & 1.098 & 1.200 \\
Company B & & & & & \\
Operating earnings & 1.0 & $\mathbf{- 0 . 2 7 6}$ & $\mathbf{0 . 7 9 0}$ & 1.193 & 1.435 \\
Cash flow from operating activities & 1.0 & $\mathbf{0 . 6 2 3}$ & 1.034 & 1.440 & 1.776 \\
Quality of operating earnings & 1.0 & $\mathbf{- 2 . 2 6 0}$ & 1.309 & 1.207 & 1.237 \\
Depreciation expenses & 1.0 & $\mathbf{1 . 4 2 2}$ & 0.799 & 1.209 & 1.301 \\
Company C & & & & & \\
Operating earnings & 1.0 & $\mathbf{0 . 3 0 1}$ & $\mathbf{0 . 8 6 4}$ & 1.333 & 1.321 \\
Cash flow from operating activities & 1.0 & $\mathbf{0 . 5 1 4}$ & 1.072 & 1.185 & 1.323 \\
Quality of operating earnings & 1.0 & 1.710 & 1.242 & 0.890 & 1.001 \\
Depreciation expenses & 1.0 & 2.824 & 2.615 & 2.144 & 2.274 \\
Company D & & & & & \\
Operating earnings & 1.0 & $\mathbf{0 . 4 6 6}$ & 1.512 & 2.104 & 2.560 \\
Cash flow from operating activities & 1.0 & $\mathbf{0 . 9 8 9}$ & 1.032 & 1.114 & 1.286 \\
Quality of operating earnings & 1.0 & 2.171 & 0.683 & 0.529 & 0.502 \\
Depreciation expenses & 1.0 & 1.126 & 0.707 & 0.707 & 0.621 \\
Company E & & & & & 0.597 \\
Operating earnings & 1.0 & $\mathbf{- 0 . 3 6 8}$ & $\mathbf{- 0 . 9 6 9}$ & 0.414 & 0.480 \\
Cash flow from operating activities & 1.0 & $\mathbf{0 . 1 1 6}$ & $\mathbf{- 0 . 3 7 0}$ & 0.580 & 0.805 \\
Quality of operating earnings & 1.0 & $\mathbf{- 0 . 3 2 5}$ & $\mathbf{0 . 3 8 2}$ & 1.402 & $\mathbf{1 . 0 4 9}$ \\
Depreciation expenses & 1.0 & $\mathbf{1 . 8 0 1}$ & 0.403 & 0.449 \\
\hline
\end{tabular}

Although the quality of operating earnings in Company A is comparatively low over the 14-year period, the quality in both 2016 and 2017 fiscal years is considerably higher than in the 2004 fiscal year due to the gradual recovery of cash flow from operating activities against the decline in operating profits, and owing to the effect of depreciation expenses on cash flow (or on the durability of exploiting investment) that were maintained a certain 
level in spite of the decline in operating revenues. In Company B, the quality of operating earnings in the 2006 and 2007 fiscal years exceeded the 2004 level of as a result of the company smoothly recovering operating earnings as well as cash flow from operating activities, despite the fact that the Lehman shock struck a serious blow to its business. Company $\mathrm{C}$ also recovered its operating earnings as smoothly as $\mathrm{B}$ following the shock in 2008. However, the quality of operating earnings is a little stagnant because cash flow from operating activities could not respond to the growth of operating earnings.

In contrast to these situations, the quality of operating earnings in Company D dropped sharply because cash flow from operating activities and depreciation expenses could not grow in comparison with operating profit. Company E was not able to recover from the Lehman shock even many years later and the quality of operating earnings did not return to the 2004 level due to the decline in operating earnings, cash flow from operating activities, and depreciation expenses. Therefore, the high quality of operating profit for the 14-year period resulted from extremely low operating earnings and comparatively high cash flow from operating activities, and concurrently low depreciation expenses, which not only made capital maintenance difficult, but was also connected with this low value of quality. In this case, it may be a bit perilous to judge enterprise slack only through the long-term quality of operating earnings.

It is clear from Table 5 that, as shown in Figures 1 and 2, the instability of enterprise slack in D and E companies, together with the decline in depreciation expenses, should be judged as weakening the operating earnings quality for the duration of the 14-year period. Thus, enterprise slack must be studied not only through its aspects of flow and stock, but also by using cash flow analysis. At the same time, not only is enterprise slack notably influenced by opportunities and risks arising at a given point in time, but it also has an important meaning in terms of the ability of enterprises to cope with these opportunities and risks.

Moreover, as clarified above, because the large differential between operating earnings and cash flow from operating activities is also related to depreciation expenses, it must be examined how these depreciation expenses are linked with cash or highly liquid assets. In the case of Company E, although depreciation expenses grew slowly, its ratio to operating expenses during the 14-year period is very high (4.067) in contrast to ratios under 1.0 in the other four companies. Furthermore, the ratio of depreciation expenses to cash flow from operating activities is high (1.4) compared with ratios 0.6 and under in other companies (see Table 4). This also highlights one problem in estimating the soundness of enterprise slack by using long-term quality of operating earnings, as cash flow related to depreciation expenses is only used to maintain the continuation of the enterprise rather than to fund new opportunities and cope with risks under uncertain business environment. In this sense, to measure the quality of operating earnings more objectively, it is necessary not only to analyze the relationship of operating earnings with cash flow from operating activities, but also to clarify "the certainty and likelihood or frequency of the earnings" and understand "the nature of the transactions and accounting principles giving rise to a particular income or expense item" (Deloitte, 2009, p. 5). This specific topic is not discussed further here since this paper is focused on examining the general relationship of enterprise slack with the quality of operating profit.

\subsection{Enterprise Slack, Cash Flow, and Business Activities}

The real state of slack as stock and flow is clarified by measuring not only their changes but also the relation between the quality of operating profit and its trends across each period. It is the actual situation of slack that decides the sustainable growth of enterprise business. Table 6 considers the relationship of investment with cash flow. Company B carries out global development strategy and actively depends on external funding to conduct its active investment activities. Company A conducts its investment activities within the sphere of cash flow from operating activities. Company $\mathrm{C}$ invests within the limit of cash flow from operating activities and at the same time tries to increase the amount of cash on hand. Company D strives for competence in its business foundation by using free cash flow and reducing cash on hand to pay back external funds. Company E conducts investment activities after reinforcing the shrunk cash flow from operating activities by raising fund externally. As a result, investment is 1.34 times higher than cash flow from operating activities and naturally the balance between investment and this cash flow is supplied by external financing. Enterprise slack is also deeply connected with these situations in investment and financial activities. 
Table 6. Cash flows from investment and financing in five Japanese companies, 2004-2017 (in hundreds of millions of yen)

\begin{tabular}{llllll}
\hline Companies & $\mathrm{A}$ & $\mathrm{B}$ & $\mathrm{C}$ & $\mathrm{D}$ & $\mathrm{E}$ \\
\hline CFI/CFO & $-63.2 \%$ & $109.6 \%$ & $-98.2 \%$ & $-80.3 \%$ & $-134 \%$ \\
CFF/FCF & $-96.5 \%$ & $169.2 \%$ & $583.3 \%$ & $-105.9 \%$ & $-117 \%$ \\
CFO & 81,848 & 404,862 & 134,473 & 89,528 & 18,231 \\
CFI & $-51,766$ & $-427,549$ & $-131,272$ & $-71,892$ & $-24,434$ \\
FCF & 30,082 & $-22,687$ & 2,375 & 17,636 & $-6,203$ \\
CFF & $-29,033$ & 38,389 & 13,854 & $-18,669$ & 7,259 \\
\hline
\end{tabular}

Note. CFI: cash flow from investments; CFO: cash flow from operating activities; FCF: free cash flow (CFO-CFI); CFF: cash flow from financing activities.

As enterprise slack is closely associated with the creation of profit opportunities and coping with risks, it must be analyzed from the perspective of earned surplus and undistributed profits and their trends over time, and in relation to cash flow from operating activities, investment, and financial activities. Additionally, the functions of enterprise slack are fulfilled in order to ensure that research and development expenses are sufficiently secured within sales amount and R\&D activities are normally implemented. These conditions make ambidexterity and the balance of exploitation and exploration possible. We can more distinctly inquire into some of these issues concerning enterprise slack in the five companies by examining the relationship between the growth of sales volume with trends in R\&D expenses (see Table 7).

Table 7. Changes in sales volume and R\&D expenses in five Japanese companies in 2017 compared with 2004 base levels $(2004=1.00)$

\begin{tabular}{llllll}
\hline Companies & A & B & C & D & E \\
\hline Sales volume & 1.18 & 1.58 & 1.78 & 1.00 & 0.96 \\
R\&D expenses & 1.20 & 1.47 & 1.61 & 0.84 & 0.68 \\
\hline
\end{tabular}

Companies A, B, and C maintained enterprise stock and the growth of R\&D spending was maintained through stable sales volumes attained with durable business growth through developing investment activities attuned to new enterprise strategy and using exploitation and exploration properly based on pertinent financing from external sources or by returning excessive funds for this purpose. In contrast to these companies, the low growth in sales volume led to a decline in R\&D expenses in Companies D and E. This condition coincides with enterprise slack. Therefore, enterprise slack is produced in the implementation process of enterprise strategy based on opportunity creation and countermeasures against risks and organizational activities that continuously support this strategy and improvement activities, while it is also a fundamental factor for making investment, financing, and daily R\&D activities possible.

\section{Theoretical Approach: Analyzed Results and the COLC Model}

After providing a general overview of enterprise slack, this paper then inquired into the actual relationship between enterprise slack and business strategy in the five Japanese manufacturing companies. Next, keeping opportunity/risk management in mind, we will describe the function and role of slack in the COLC model in relation to strategic planning. Coping with uncertainty through feed forward accounting control is a main theme in this model, where the first expected profit is concretely forecasted through proactive variance analyses between expected value and estimated value in profit opportunities and risks (forecast profit opportunity variance $=$ expected profit opportunities - estimated profit opportunities; forecast risk variance $=$ expected risks - estimated risks) and proactive improvement or re-examination of innovation plans. Then, for control of business activities in a period, target profit is led through a comparison of the expected profit with estimated profit based on practical condition and proactive improvement and possible innovation for reducing differences. This target profit gives a base to calculate target cost. The actual control process starts after these stages. According to the target profit and target cost, the first improvement and innovation (or exploitation and exploration) are carried out and then production processes are efficiently and effectively managed. Lastly, the actual profit that occurred in this process is compared with the target profit and information on opportunity cost variance (operation variance) leads to optimum profit planning in the next period. 
The main matter of concern in this paper is that enterprise slack ensures that improvement and innovative activities are pursued to reduce variances recognized in the above process. Without slack, any business and control behavior could not be carried out. Even if enterprises depend upon employees' efforts toward cost reduction and supply chains' endeavor to reduce prices, they would need some source of funding to implement the changes. Investment funds for globally innovative competition should be used in areas such as technology to build the information and resources needed to activate employees' and suppliers' efforts more effectively, and to correspond to radical changes of consumer demand. Not every enterprise can survive in such a competitive marketplace if it has no possible countermeasure to reform existing technologies and capacity in order to create new products in line with trends in market demand. Thus, the key question for us to consider is how enterprise can make the most of the COLC model based on enterprise slack to recognize forecast variance of opportunities/risks and drive forward and control investment and financial activity-strategy related to exploitation and exploration, or improvement and innovation, in order to reduce this variance. Improvement and innovation are closely connected with variance recognition of opportunities/risks and their management, and the undistributed profit (slack as flow) secured by continuously stable cash flow and earned reserve (slack as stock) are also indispensable for this recognition and management.

As under these conditions, accounting information such as target profit, forecast profit variance, and profit variance (opportunity cost variance) definitely decides the right direction of investments under the enterprise strategy and at the same time also affects ordinary $\mathrm{R} \& \mathrm{D}$, cost improvement, and total quality control. This information acquires an important meaning only when an enterprise sufficiently holds enterprise slack as stock and flow based on cash flow from operating activities. Therefore, the relationship between strategic planning and the COLC model can be shown visualized as a figure in which opportunities/risks and enterprise slack are at the foundation of strategic planning in the model (see Figure 3). Figure 4 shows the composition of accounting recognition, business activities, and control systems with enterprise slack as an axis in COLC model.

\section{Strategic planning}

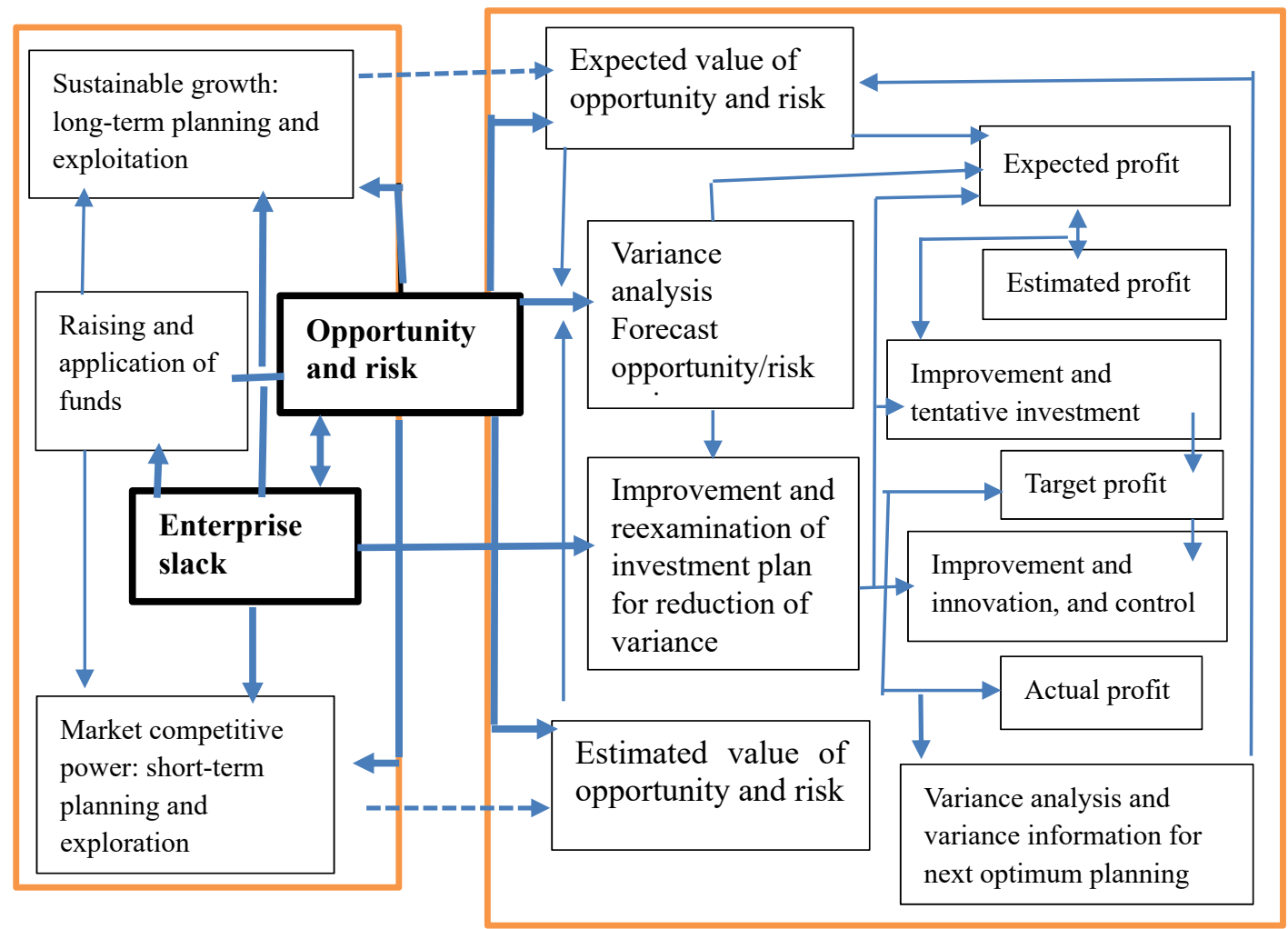

Figure 3. Strategic planning and accounting control in the COLC model

As shown in Figure 3, in the COLC model, forecast variance analysis of opportunity and risk is first implemented according to strategic plans for sustainable growth and market competition, then proactive 
improvement is carried out and rational innovation plans are examined based on enterprise slack to reduce the forecast variance, and after forecast expected profit based on this information is compared with practical estimated profit, and additional improvement and more practical innovation are examined beforehand for reduction of variance, target profit is identified. Continually defined business activities and operational management are implemented according to target profit and target cost. Figure 4 particularly indicates the process of accounting recognition and control.

The COLC model is a process that starts from (a) and arrives at (e), where enterprise slack supports proactive control, improvement or potential innovation. The re-examination of innovation plan for the reduction of variance (b), and reactive control and innovation or improvement according to strategic plan (d) are also supported by enterprise slack. Enterprise slack fulfills its function as a key component of the model as it allows practical control and investment activities to be sustained together with feed forward and feedback accounting recognition and control. Moreover, an enterprise can raise funds from external sources and be replete with owned capital through the systematic use of enterprise slack. Therefore, we should understand the substance of slack beyond merely accounting recognition. In a value creation strategy, managers in an enterprise synthetically coordinate exploitation and exploration, improvement and innovation, and their management from the viewpoints of long-term sustainable growth and short-term competitive strategy. Enterprise slack in the COLC model is the unrestricted but indispensable funds that managers can cooperatively use to carry out business strategy based on opportunities/risks in an uncertain business environment. Thus, the COLC model is a strategic profit planning and control process system in which the enterprise uses the slack as an axis to manage opportunities and risks and realize target profit through feed forward and feedback accounting control. Additionally, because discussion in this paper is limited to the relationship between slack and the COLC model, the paper did not delve into organizational structure, leadership, behavior of organizational members, organizational culture, or other such factors, even though they are essential to the effective development and use of the COLC model.

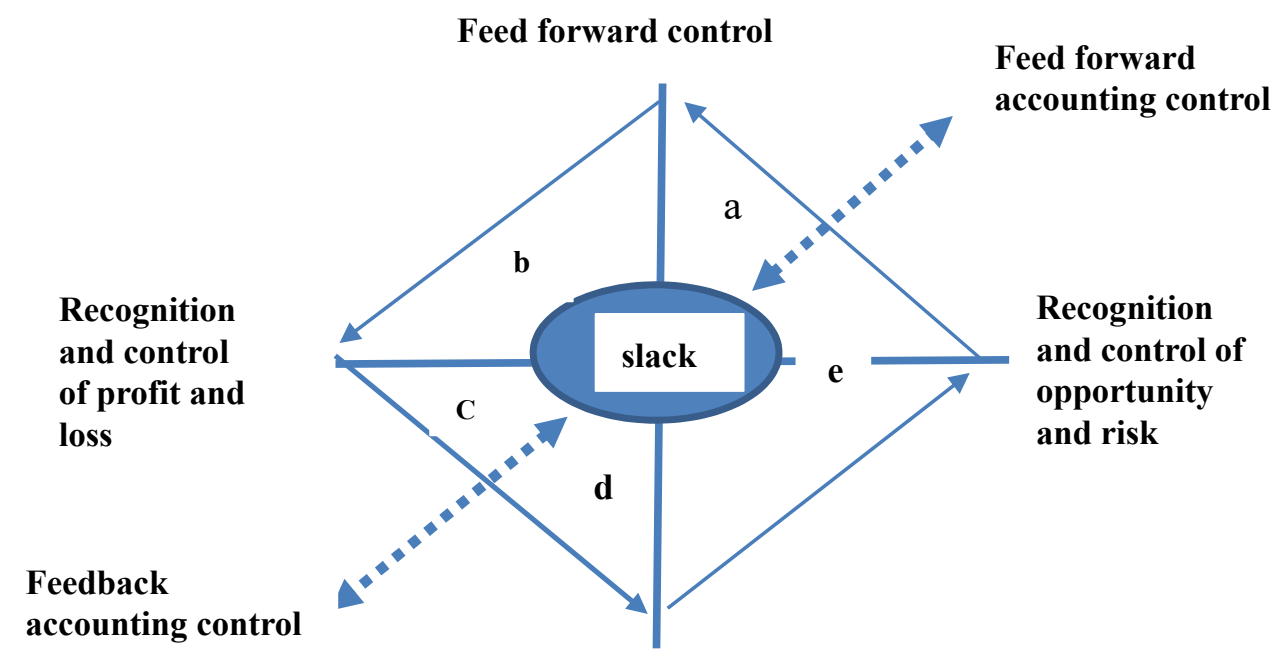

Feedback control

Figure 4. Accounting recognition and control in the COLC model

Note. a, forecast and variance analysis of opportunity and risk; b, proactive control and, improvement and preparation of innovation; c, accounting recognition of profit and loss (measurement and disclosure), and variance analysis between target profit and actual profit; $\mathrm{d}$, reactive control and efficient and effective activities for the revision of variance (implementation of improvement and innovation); e, re-examination of accounting control system and its reconstruction.

\section{Conclusion}

To examine the practical content of the COLC model, the author first inquired into the real state and meaning of the concept of enterprise slack and the strategic planning associated with this concept. Second, on the basis on 
this analysis, this paper made clear the relationship between variance analysis and control system and their relations with exploitation and exploration. Third, it illustrated how enterprises implement competitive strategy and sustainable growth strategy organically with slack as an axis in the feed forward and feedback cycle. The issues discussed in this paper are intricately related to the core concepts discussed in Management, Uncertainty, and Accounting and serve as a valuable compliment to that book. In addition, this paper newly elucidates that the substance of enterprise slack is supported by cash flow and its stability. Using slack to cope with changes in the business environment not only supports long-term growth and short-term competitive power of enterprise, but also fosters the generation of additional slack through these strategic successes and competitive powers. The COLC model truly recognizes and controls this reciprocal relation between the slack and enterprise strategies.

\section{References}

Carpenter, R. E., \& Petersen, B. C. (2002). Capital Market Imperfection, High-Tech Investment, and New Equity Financing. The Economic Journal, 112(477), F54-F72. https://doi.org/10.1111/1468-0297.00683

Chung, K. H., \& Wright, P. (1998). Corporate Policy and Market Value: A q-Theory Approach. Review Quantitative Finance and Accounting, 11(3), 293-310.

Deloitte. (2009). Quality of earnings, Focus on integrity and quality.

Fujita, T. (2018). Misunderstanding of Overflowing Internal Reserve in Japanese Firms. Monthly Journal: Capital Market, 52-60.

Gschwantner, S., \& Hiebl, M. R. W. (2016). Management control systems and organizational ambidexterity, Journal of Management Control, 27, 373-405. https://doi.org/10.1007/s0018-016-0236-3.

Gurd, B., \& Helliar, C. (2017). Looking for leaders: 'Balancing' innovation, risk and management control systems. The British Accounting Review, 49(1), 91-102. https://doi.org/10.1016/j.bar.2016.10.008

Hall, B. H. (1992). The Financing of Research and Development, Oxford Review of Economic Policy, 18(1), 35-51. https://doi.org/10.3386/w8773

Himmelberg, C. P., \& Petersen, B. C. (1994). R\&D and Internal Finance: A Panel Study of Small Firms in High-Tech Industries. The Review of Economics and Statistics, 76(1), 38-51.

Imai, N. (2014). Concept of Proactive Slack: A Study on Essence of Toyota's Performance Accounting. Journal of Japan Management Diagnosis, 14, 41-48.

Imai, N. (2016). Toyota's Production System and Budget Bias: Study on Types of Thought of Resource Management. Meijo Review (Meijo University), 15-25.

Iwase, T., \& Sato, M. (2017). Internal Reserve (Earned Reserve) and Profit-sharing in Japanese Firms from the viewpoint of Corporate Business Statistical Analysis. Finance, 7, 86-95.

Josephson, B. W., Johnson, J. L., \& Mariadoss, B. J. (2016). Strategic marketing ambidexterity: antecedents and financial consequences, Journal of the Academic Marketing Science, 44(4), 539-554. https://doi.org/10.1007/s11747-015-0438-5

Myers, S. C., \& Majluf, N. S. (1984). Corporate Financing and Investment Decisions When Firms Have Information that Investors Do Not Have. Journal of Financial Economics, 13(2), 187-221. https://doi.org/10.3386/w1396

Nishimura, A. (2015). Comprehensive Opportunity and Lost Opportunity Control Model and Enterprise Risk Management. International Journal of Business and Management, 10(8), 73-87. https://doi.org/10.5539/ijbm.v10n8p73

Nishimura, A. (2016). Foreign Exchange Risk and Profit Improvement in the Comprehensive Opportunity and Lost Opportunity Control Model. International Journal of Business and Management, 11(4), 1-13. https://doi.org/10.5539/ijbm.v11n4p1

O'Reilly, C. A., \& Tushman, M. L. (2013). Organizational Ambidexterity: Past, Present, and Future. The Academy of Management Perspectives, 27(4), 324-338. https://doi.org/10546/amp.2013.0025

Sakanaka, Y. (2017). It is Time When Japanese Firms should Reconsider the Level of 'Internal Reserve'. Economist Eyes, 5, 1-3.

Sasaki, T. (2007a). Internal funds and R\&D investment (1). NFI Research Review.

Sasaki, T. (2007b). Internal fs and R\&D investment (2). NFI Research Review. 
Sasaki, T. (2008). Internal funds and R\&D investment (3). NFI Research Review.

Ylinen, M., \& Gullkvist, B. (2014). The effects of organic and mechanistic control in exploratory and exploitative innovations, Management Accounting Research, 25(1), 93-112. https://doi.org/10.1016/j.mar.2013.05.001

\section{Notes}

Note 1. Nishimura, A. (2019). Management, Uncertainty, and Accounting: Case Studies, Theoretical Models, and Useful Strategies, Palgrave Macmillan. For information on the COLC model, see chapters 8, 9, and 10, as well as Nishimura, 2017; 2018.

Note 2. The five companies that are covered in the case study have actively grappled with technological innovation and development of new products and their total assets and number of employees in 2017 fiscal year are as follows:

\begin{tabular}{|c|c|c|c|c|c|}
\hline Companies & $\mathrm{A}$ & $\mathrm{B}$ & $\mathrm{C}$ & $\mathrm{D}$ & $\mathrm{E}$ \\
\hline Total assets (trillion of yen) & 5.2 & 50.5 & 19.3 & 19 & 2 \\
\hline $\begin{array}{l}\text { Number of employees (tens of thousands of } \\
\text { persons) }\end{array}$ & 20 & 37 & 20 & 30 & 4.2 \\
\hline Main industry & $\begin{array}{l}\text { Electric } \\
\text { machinery }\end{array}$ & Automobile & Automobile & $\begin{array}{l}\text { Electric } \\
\text { machinery }\end{array}$ & $\begin{array}{l}\text { Electric } \\
\text { machinery }\end{array}$ \\
\hline
\end{tabular}

Note. Employees includes overseas and irregular employment: see www.kabupro.jp/yuho/---htm.

Note 3. Himmelberg and Petersen (1994) more positively study Schumpeter's argument, that is "internal finance is a determinant of R\&D investment," and point out that although the practices of large companies generally fit under this argument, "the principle determinant of investment for small, high-tech firms is internal finance" (p. 49).

Note 4. Iwase and Sato (2014) explain internal reserve as "earned reserve" and the "amount of subtracted dividend from profit in the current period as internal reserve as flow" (p. 86). They focus on "internal reserve" or undistributed profits within the firm. According to them, in this paper, to make clearer the difference between internal reserves in the income statement and on the balance sheet, the author defines "undistributed profit in the form of internal reserve as flow" and earned reserve in the form of "internal reserve as stock," since both represent "undistributed profit reserved within the firm" and are similar to cash and have high liquidity, although earned reserve is a long-term form of internal reserve or shown as stock on the balance sheet. Meanwhile, internal reserve as flow is related to the current period or shown as undistributed profit in the profit and loss statement. In this paper a combination of "slack as flow" and "slack as stock" is named enterprise slack.

Note 5. Since the 1990s, assets in foreign currencies have increased in Japanese companies as a result of moving their production bases overseas and increasing acquisitions of foreign enterprises, while "borrowing transaction in foreign currency has not advanced by reasons of comparatively low rate of interest in yen, the difficult of raising foreign currencies of rising nations and high hedging cost due to interest rate of discrepancy between home and abroad which result in large exchange risk in balance sheets of Japanese firms" (Fujita, 2018, p. 57)

\section{Copyrights}

Copyright for this article is retained by the author(s), with first publication rights granted to the journal.

This is an open-access article distributed under the terms and conditions of the Creative Commons Attribution license (http://creativecommons.org/licenses/by/4.0/). 